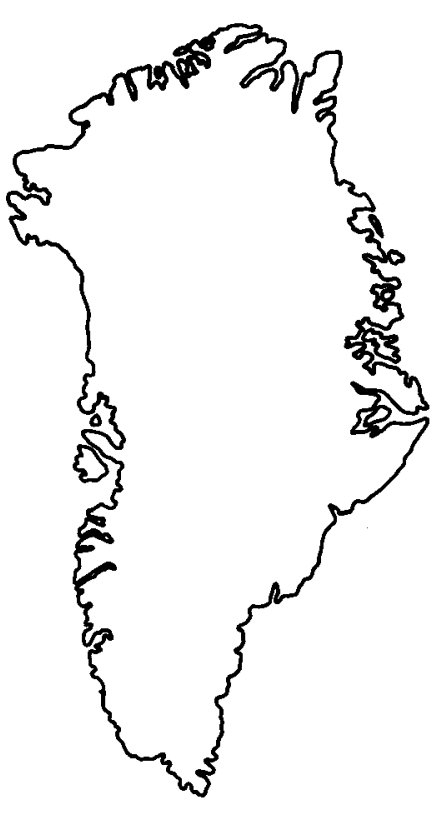

\section{Revision of Ordovician-Silurian gastropods from North Greenland}

\author{
John S. Peel \\ Ordovician-Silurian gastropods from western North Greenland \\ collected by the British Arctic Expedition (1874-1876) and \\ described by R. Etheridge (1878) are reviewed. Offleyotrochus $\mathrm{n}$. \\ gen. is proposed, with type species $O$. naresi (Etheridge, 1878) \\ from the Silurian of Offley $\varnothing$, and assigned to the family \\ Euomphalidae.
}

J.S.P. Grønlands Geologiske Undersøgelse, Øster Voldgade 10, DK-1350 Copenhagen K, Denmark.

The British Arctic Expedition of 1874-1876 under the leadership of Sir George Nares (summary and bibliography in Koch, 1940), in addition to significant geological observations (Feilden \& De Rance, 1878), made large collections of fossils from both western North Greenland and adjacent north-eastern Ellesmere Island. These fossils, described by Etheridge (1878), included the first well described Lower Palaeozoic faunas from North Greenland and provided a basis for early attempts at regional geochronology. Etheridge (1878) listed more than 90 species of Palaeozoic fossils of which two thirds were said to be derived from strata of "Silurian" age in the pre-Lapworth sense to include both Ordovician and Silurian of current usage. Twelve new species or varieties were named, all but one of these from the Ordovician-Silurian.

A general faunal revision of Etheridge's described material, housed in the British Museum (Natural History), London, has seemingly not been undertaken, although several individual specimens, species or higher taxa have been referred to by subsequent authors, e.g. individual corals by Scrutton (1975) and McLean (1977). However, few of the then new taxa described by Etheridge (1878) are adequately known, although the possible age priority over subsequently described species gives these taxa considerable systematic importance.

Etheridge (1878) recorded 10 species of Ordovician-Silurian gastropods from the area adjacent to Kennedy Channel, of which three were new species. Raphistoma aequale(?), a species of Holopella and Maclurea magna were reported only from Ellesmere Island and are not considered further. A preliminary discussion of the remaining species, collected from Greenland, is given below. It should be noted that not all the gastropod specimens referred to by Etheridge (1878) or registered in the accessions catalogue of the British Museum (abbreviated subsequently to $\mathrm{BM}$ ) could be located in the time available.

With the exception of the specimen of Maclurites, all the examined specimens discussed below originate from localities with Silurian strata. It is presumed that the material was collected more 
or less in situ, and there is no evidence from the fossil identifications to suggest otherwise. Maclurites is a characteristic Ordovician genus known to be widely distributed in Lower, Middle and Upper Ordovician strata in North Greenland (Troedsson, 1928; Christie \& Peel, 1977). The Silurian taxa are not useful for precise age determination, at this time.

Silurian gastropods have subsequently been described from the same area of Greenland by Poulsen (1974), on the basis of collections made by Lauge Koch a half century previously. The fauna possibly has a single high spired gastropod in common with Etheridge's material, together with the ubiquitous platyceratids, but is not otherwise similar.

\section{Murchisonia (?Murchisonia) latifasciata Etheridge, 1878}

Fig. 1 A, B, D

Murchisonia latifasciata Etheridge, 1878, p. 600-601, Plate XXVII, fig. 1.

Murchisonia,? sp., Etheridge, 1878, p. 601, Plate XXVII, fig. 2.

Holotype. BM 89165, collected from the Silurian of Offley $\varnothing$, Coppinger collection C.01.X.

Additional material. BM 89164, a poorly preserved specimen from Offley $\varnothing$ which Etheridge (1878) referred to Murchisonia,? sp. is almost certainly referable to $M$. (?M.) latifasciata (fig. 1 A).

Discussion. This species is delimited from other Silurian species of the Murchisoniacea principally on account of its large size - the holotype when complete probably approached $15 \mathrm{~cm}$ in height, of which about $9 \mathrm{~cm}$ are currently preserved. Etheridge's original illustration of the holotype is reasonably correct and clearly shows the rather wide selenizone between bordering threads. The selenizone is located rather low on the whorl periphery causing $M$. (?M.) latifasciata to resemble M. (?Hormotoma) cingulata (Hisinger, 1829) from the Silurian of Gotland and $M$. (H.) sp. A of Peel (1977) from the Early Silurian Ross Brook Formation of Arisaig, Nova Scotia. The Arisaig species, however, has steeply inclined, nearly orthocline, growth lines above the selenizone while corresponding growth lines in $M$. (?M.) latifasciata are much more oblique. $M$. (H.) cingulata, as illustrated by Lindström (1884, pl. XII, figs 9-10), is apparently distinguished from $M$. (?M.) latifasciata by its smaller size, and relatively narrower selenizone with less pronounced bordering threads.

The subgeneric position of all these species is to some extent unsatisfactory since assignment to Murchisonia s.s. or Hormotoma depends to a large extent on the degree of emphasis of the cords bordering the selenizone. In Hormotoma the selenizone is delimited by threads while in Murchisonia s.s. prominent cords are often present. The three species discussed here lie somewhere between the two extremes.

\section{Undetermined murchisoniacean}

Fig. $1 \mathrm{C}$

Material. BM G.14088, a single poorly preserved specimen from the Silurian of Offley $\varnothing$, Coppinger collection C.01.aa. 

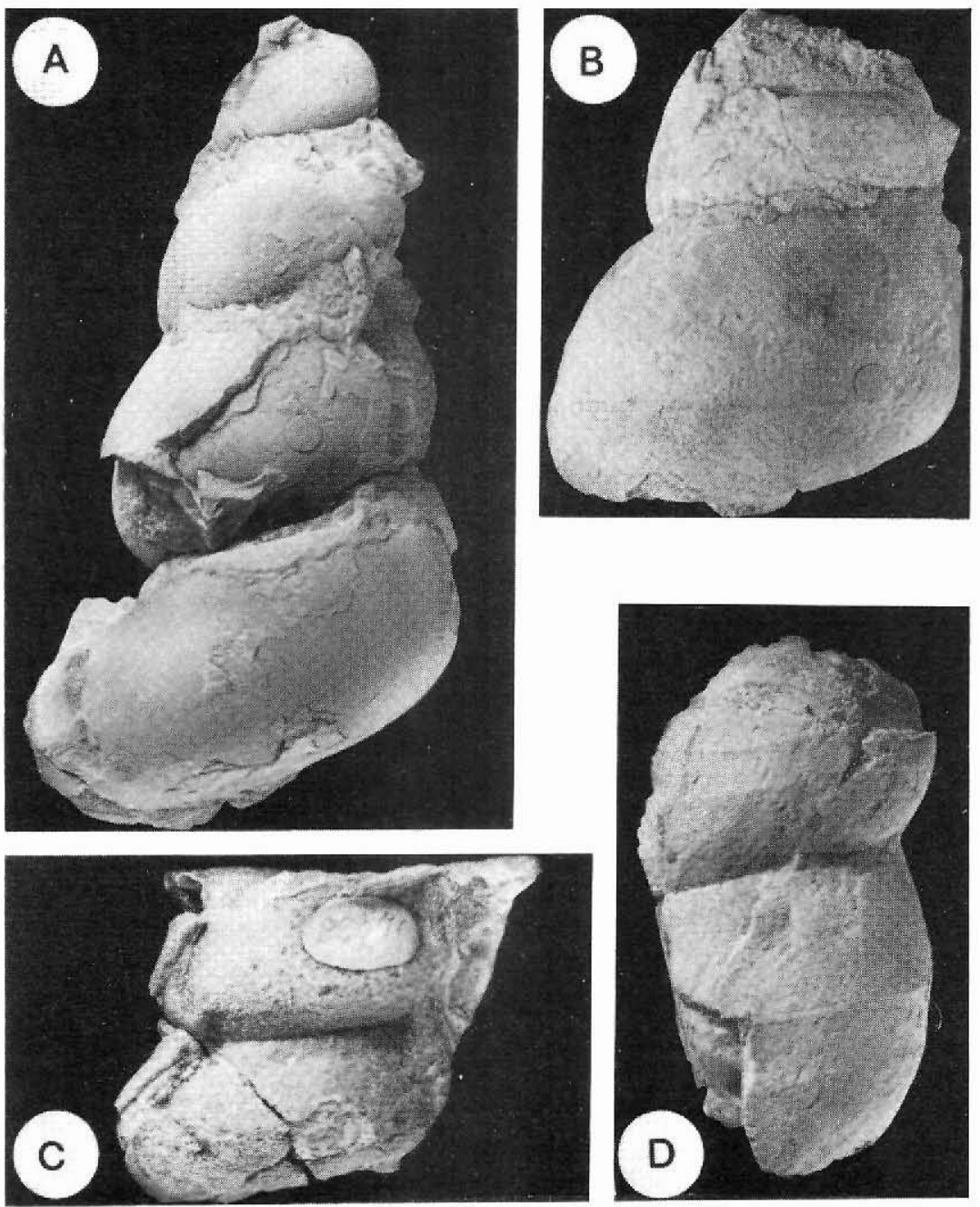

Fig. 1. A,B,D, Murchisonia (?Murchisonia) latifasciata, $\times 1$. A, BM 89164; B,D, BM 89165 , holotype. C, Undetermined murchisoniacean, BM G.14088, × 1.5 .

Discussion. This high spired murchisoniacean gastropod was neither illustrated nor discussed by Etheridge (1878), but is too poorly preserved for determination. Poulsen (1974) referred a morphologically similar specimen from the Silurian of Kap Morton, northern Washington Land to Michelia? persimilis sp. nov., while Whiteaves (1884) had referred a similar shell from the Silurian of Canada to Murchisonia turritiformis. The correct generic assignment of the species, or group of species is uncertain, but the Offley $\varnothing$ example does not contribute to the issue. 
Type species. Helicotoma naresi Etheridge, 1878.

Derivation of name. After Offley $\varnothing$, western North Greenland, the collection locality of the holotype of the type species.

Diagnosis. Seemingly discoid, dextral gastropod with shallow, widely phaneromphalous umbilicus and a V-shaped emargination on the umbilical wall near the adpressed suture with the previous whorl.

Discussion. The upper surface of Offleyotrochus is unfortunately unknown, although characters of the basal surface, particularly the subsutural emargination, are quite distinctive. Helicotoma Salter, 1859, an Early - Middle Ordovician genus (Knight et al., 1960), has a more convex base and a narrower, deeper umbilicus without the diagnostic emargination of Offleyotrochus.

Common Silurian genera which may appear superficially similar to the North Greenland genus include Euomphalopterus Roemer, 1876, Centrifugus Bronn, 1834, and Poleumita Clarke \& Ruedemann, 1903. Euomphalopterus has a wide peripheral flange seemingly wanting in Offleyotrochus, and a narrow umbilicus with incised rather than adpressed sutures. In addition, growth lines in Euomphalopterus on the base of the whorl are concave adaperturally, not convex as in Offleyotrochus, and show no subsutural emargination. Growth lines in Centrifugus are convex adaperturally in the immediate vicintity of the tiny peripheral emargination, but soon sweep with adaperturally concave form into the widely phaneromphalous umbilicus; a subsutural emargination is not developed. In Poleumita and related euomphalaceans, the umbilicus tends to be widely phaneromphalous, as in Offleyotrochus, but the base is generally less flattened. A subsutural emargination is not present although Knight (1941, p. 122) noted a slight adapertural swing of the growth lines immediately adjacent to the umbilical suture in the Carboniferous Euomphalus pentangulatus Sowerby, 1814.

Affinities and suprageneric classification. Offleyotrochus most closely resembles Centrifugus, a characteristic Gotland snail of slightly younger, Late Silurian, age than the Greenland occurrence. There is some suggestion in Offleyotrochus of a narrow peripheral angulation of the type seen in Bronn's genus. The latter is also characterised by a subsutural sinus but on the upper surface of the whorl as distinct from on the umbilical, as in Offleyotrochus. Although the umbilical emargination is absent in Centrifugus, the adapertural concavity of the growing edge is sufficient to excavate a broad shallow sinus in the basal lip, with growth lines curving adaperturally as they approach the umbilical suture. However, there is little to suggest that this emargination is morphologically or functionally related to the narrower, deeper emargination seen in Offleyotrochus.

Offleyotrochus is tentatively referred to the archaeogastropod family Euomphalidae de Koninck, 1881 sensu Knight et al. (1960), as modified by Taylor \& Sohl (1962), to lie close to Centrifugus. 
Offleyotrochus naresi (Etheridge, 1878)

Fig. 2

Helicotoma Naresii Etheridge, 1878, p. 602, Plate XXVII. fig. 3.

Holotype. BM 89163, collected by Coppinger from the Silurian of Offley $\varnothing$.

Additional material. Etheridge (1878) referred only the holotype to his species, although an additional, poorly preserved specimen from Offley $\varnothing$ (BM G.14086 from Coppinger collection C.01.K) is undoubtedly conspecific.

Description. Large, widely phaneromphalous, probably discoidal gastropod with slowly expanding whorls. Apical whorls and upper surface unknown. Base with broad, flattened basal surface passing via angular umbilical shoulder into a concave subsutural channel (the umbilical wall), the adumbilical margin of which is adpressed against the base of the previous whorl. Aperture poorly known; basal lip convex adaperturally, curving strongly into the subsutural channel which is the locus of a V-shaped emargination. Base ornamented with growth lines; shell structure and thickness unknown.

Discussion. About three and a half whorls are preserved in the holotype (fig. 2 A) but the apex and aperture are both lacking.
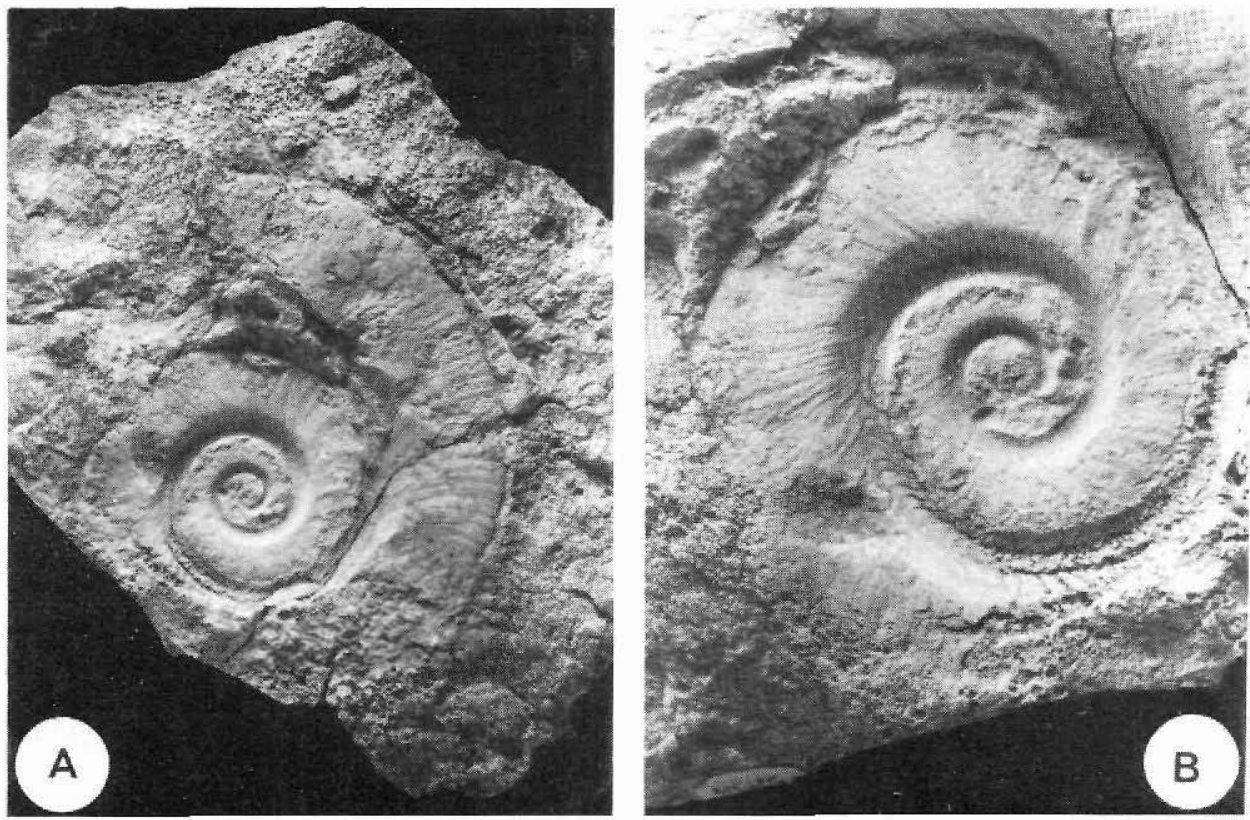

Fig. 2. Offleyotrochus naresi, BM 89163 , holotype, umbilical surface. A, $\times 1$; $\mathrm{B}, \times 2$, to show the emargination at the suture with the previous whorl. 


\section{Platyceras (Platyostoma) naticoides (Etheridge, 1878)}

Fig. 3 C, E-G

Platyceras naticoides Etheridge, 1878, p. 603-604, Plate XXVII, fig. 4, non fig. 4 a.

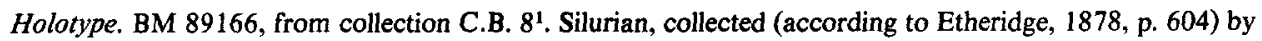
Coppinger from Bessels Bay (= Bessel Fjord), Washington Land.

Additional material. In addition to the figured specimen of Etheridge (1878), the following specimens from the Silurian of Bessel Fjord were located: BM 89178, BM G.14093, BM G.14096-14105, BM G.14107, from collections attributed to Feilden. Coppinger and, possibly Hart.

Discussion. The classification of most platyceratid gastropods at the generic as well as specific levels is not on a sufficiently firm footing to justify discussion of the status of Etheridge's new species. Platyceras naticoides is referred to the subgenus Platyostoma Conrad, 1842 rather than to the capuliform Platyceras s.s. Conrad, 1840. Platyostoma is characterised by a rather naticiform whorl profile, often with a narrow umbilicus of the type seen in the Washington Land material.

Platyceras (Platyostoma) cf. P. (Pl.) cornutum (Hisinger, 1837)

Fig. 3 A, B, D

Acroculia haliotis (Sow.), Etheridge, 1878, p. 603.

Figured material. BM G.14090, BM G.14095 from the Silurian of Bessel Fjord, Washington Land.

Additional material. BM G.14091, BM G.14092, BM G.14094, Silurian of Bessel Fjord. The two figured, and three additional specimens are from collections C.B. 25, C.B. 9, B. 22, C.B. 11, B. 31.

Discussion. Etheridge (1878) commented that "many examples of this shell are in the collection, and, as usual, as many varieties; for no two are alike". The species was not illustrated but 6 specimens labelled Acroculia haliotis were located in the British Museum (Natural History) collections. One of these, BM G.14093, labelled C.B. 8 Bessels Bay (= Bessel Fjord), would appear to be an example of $P$. (Pl.) naticoides, above. A second, BM G.14095, may be a juvenile of Naticopsis (?) sp., discussed below, but is tentatively retained here. The remaining examples are of a naticiform platyceratid with a much greater rate of whorl expansion than in $P$. (Pl.) naticoides. Poulsen (1974) figured similar platyceratids from Kap Morton, northern Washington Land, which he also referred to Hisinger's species. 

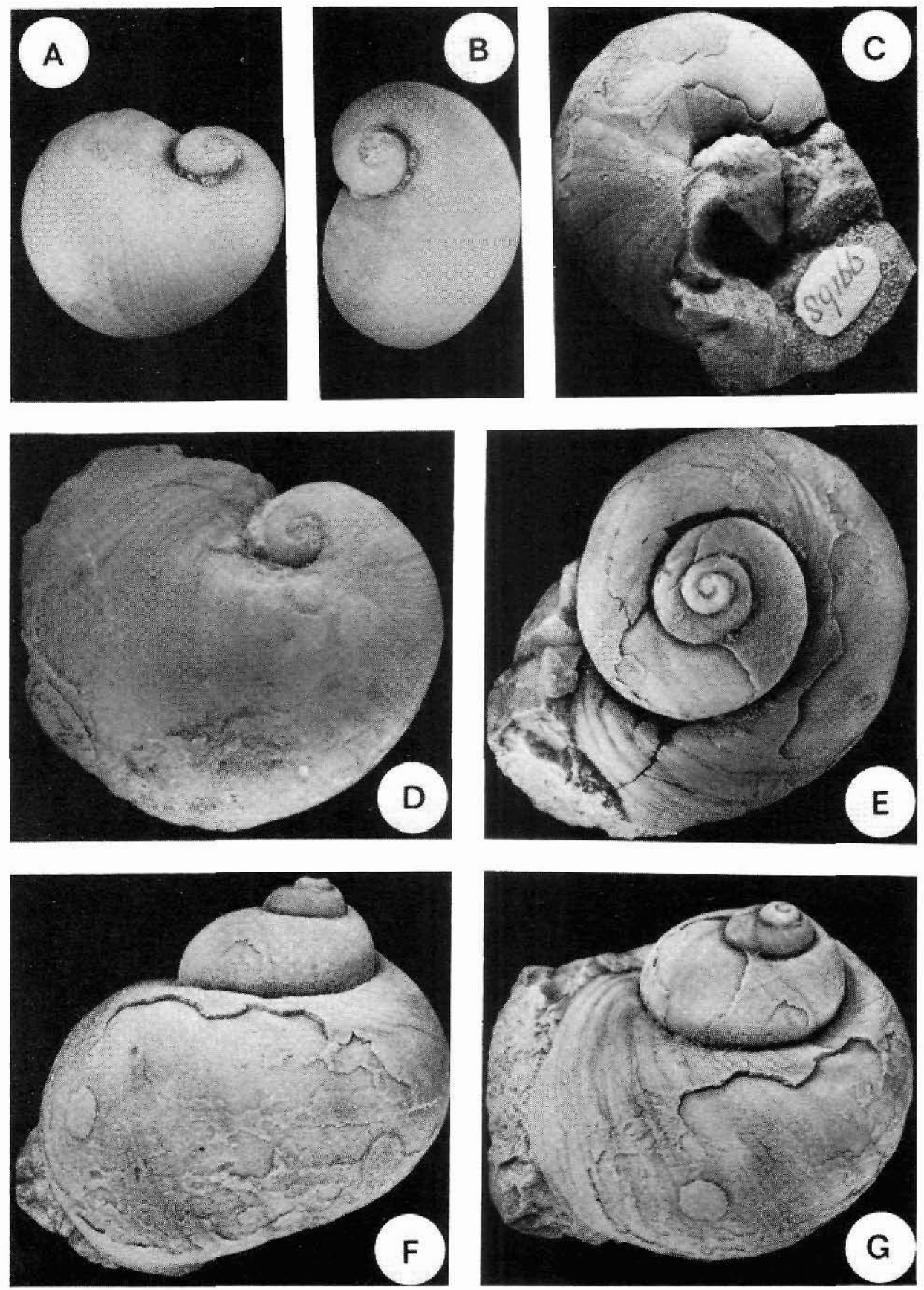

Fig. 3. A,B,D, Platyceras (Platyostoma) cf. P. (Pl.) cornutum, $\times$ 2. A,B, BM G.14095; D, BM G. 14090. C,E-G, Platyceras (Platyostoma) naticoides BM 89166, holotype, C, $\times 1.2 ; \mathrm{E}-\mathrm{G}, \times 1.5$. 


\section{Naticopsis (?) sp.}

Fig. 4 C, E, F

Platyceras naticoides Etheridge, 1878, p. 603-604, Plate XXVII, fig. 4a, non fig. 4.

Material. BM 89167, Coppinger collection C.B. 10, from the Silurian of Bessels Bay (= Bessel Fjord).

Discussion. Etheridge (1878) recognised this specimen as a variety of the present Platyceras (Platyostoma) naticoides which was characterised by a greater rate of whorl expansion. The specimen is well preserved, although slightly flattened and with the apex missing. A narrow umbilicus is present. Growth ornamentation is slightly over emphasised in the original illustration, and forms a slight emargination near the suture. Fine spiral striations are also present. The specimen is tentatively referred to Naticopsis but, allowing for the infamous variability of platyceratids and the lack of additional material, the possibility of assignment to the latter mentioned family should not be excluded.

\section{Maclurites sp.}

Fig. 4 A, B, D

?Maclurites Logani, Etheridge, 1878, p. 606.

Figured specimen. BM G.14084, locality unknown, possibly Bessel Fjord, Washington Land or arctic Canada.

Discussion. Etheridge (1878) recorded Maclurites logani from collections made by Coppinger and Hart in Bessel Fjord. The only specimen located bearing this identification (BM G.14084) is c. $40 \mathrm{~mm}$ wide and without locality information. The label, with the identification written in pencil (subsequently?), states (also in pencil) "? Capt. H.W. Feilden coll.". In view of the confusion concerning origin, the specimen is not further discussed. Several other macluritids collected on the Canadian side of Kennedy Channel are present in the collection. Maclurites is currently restricted to the Ordovician (Knight et al., 1960).

\section{Bellerophon sp.}

Bellerophon, sp., Etheridge, 1878, p. 606.

Discussion. Etheridge (1878) recorded two specimens of a bellerophontacean gastropod from Bessel Fjord but the specimens were not located in the British Museum collections. 

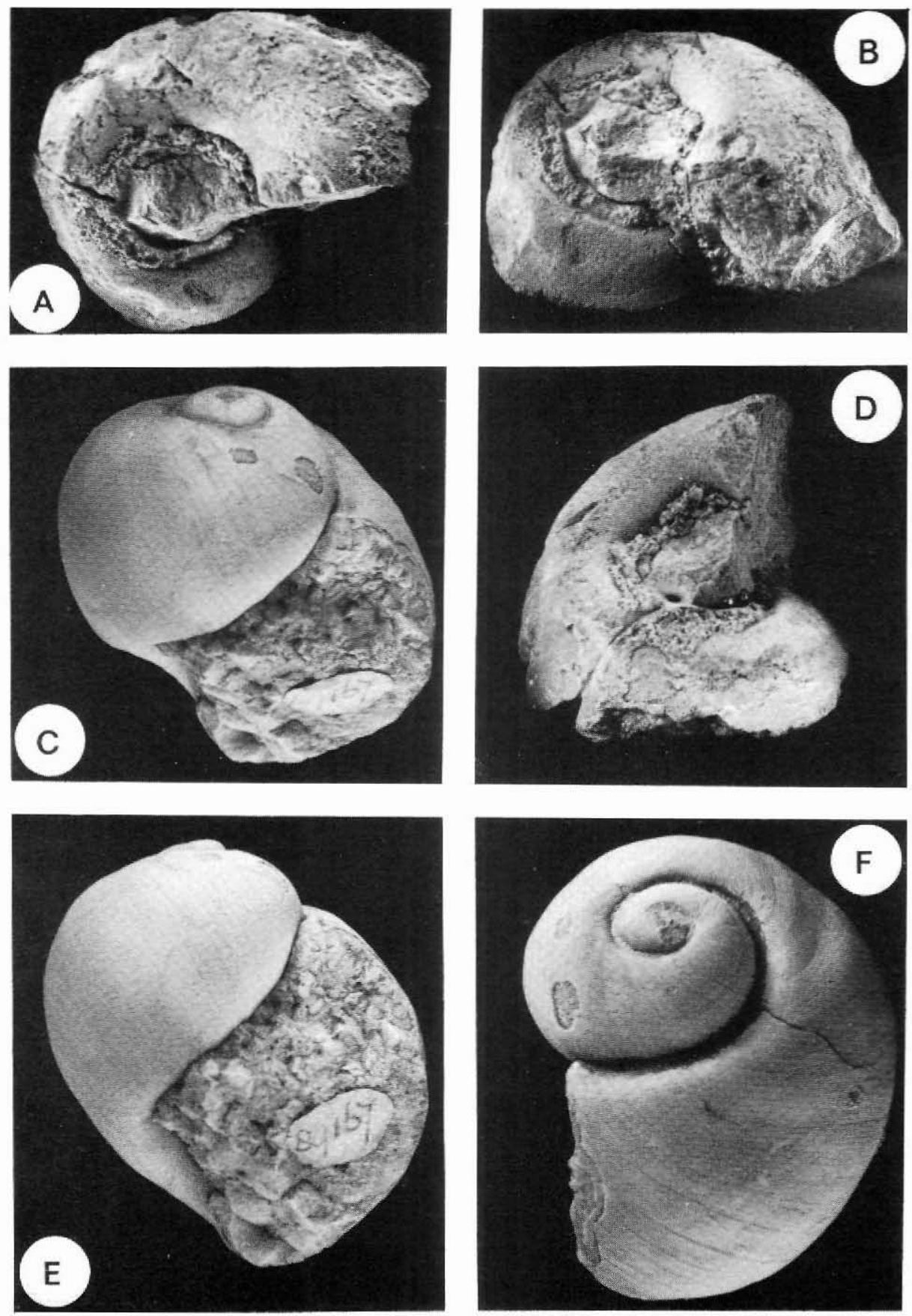

Fig. 4. A,B,D, Maclurites sp., BM G.14084, × 2. C,E,F, Naticopsis(?) sp., BM 89167, × 1.5 . 


\section{References}

Christie, R.L. \& Peel, J.S. 1977: Cambrian-Silurian stratigraphy of Børglum Elv, Peary Land, eastern North Greenland. Rapp. Grønlands geol. Unders. 82, $48 \mathrm{pp}$.

Etheridge, R. 1878: Palaeontology of the coasts of the Arctic Lands visited by the late British Expedition under Captain Sir George Nares, R.N., K.C.B., F.R.S. Quart. J1 geol. Soc. Lond. 34, 568-639.

Feilden, H.W.\& De Rance, C.E. 1878: Geology of the coasts of the Arctic Lands visited by the late British Expedition under Captain Sir George Nares, R.N., K.C.B., F.R.S. Quart. Jl geol. Soc. Lond. 34, 556-567.

Knight, J.B. 1941 : Paleozoic gastropod genotypes. Spec. Pap. geol. Soc. Am. 32, 510 pp.

Knight, J.B., Cox, L.R., Keen, A.M., Batten, R.L., Yochelson, E.L. \& Robertson, R. 1960: Systematic descriptions. In Moore, R.C. (edit.), Treatise on Invertebrate Paleontology, I, Mollusca 1, Gastropoda, I169-I331. Kansas U.P.

Koch, L. 1940: Survey of North Greenland. Meddr Grønland 130(1), 364 pp.

Lindström, G. 1884: On the Silurian Gastropoda and Pteropoda of Gotland. Kongl. Svenska Vetenskaps Akad. Handl. 19(6), $250 \mathrm{pp}$.

McLean, R.A. 1977: Early Silurian (Late Llandovery) rugose corals from western North Greenland. Bull. Grønlands geol. Unders. 121, $46 \mathrm{pp}$.

Peel, J.S. 1977: Systematics and palaeoecology of the Silurian gastropods of the Arisaig Group, Nova Scotia. Biol. Skr. Dan. Vid. Selsk. 21(2), 89 pp.

Poulsen, C. 1974: Silurian Pelecypoda, Monoplacophora, and Gastropoda from the reefy facies of the Offley Island Formation of Washington Land and Offley Island (Northwest Greenland). Biol. Skr. Dan. Vid. Selsk. 20(7), 14 pp.

Scrutton, C.T. 1975: Corals and stromatoporoids from the Ordovician and Silurian of Kronprins Christian Land, northeast Greenland. Meddr Grenland 171(4), 43 pp.

Taylor, D.W. \& Sohl, N.F. 1962: An outline of gastropod classification. Malacologia 1, 7-32.

Troedsson, G. 1928: On the Middle and Upper Ordovician faunas of northern Greenland. II. Meddr Grønland 72(1), 1, $197 \mathrm{pp}$.

Whiteaves, J.F. 1884: On some new, imperfectly characterized or previously unrecorded species of fossils from the Guelph formation of Ontario. Geological and Natural History Survey of Canada. Palcozoic fossils 3, 1, Gasteropoda, 16-36. 